\title{
CLASSIFICATION OF ROAD ACCIDENTS FROM THE PERSPECTIVE OF VEHICLE SAFETY SYSTEMS
}

\section{VÁCLAV JIROVSKÝ}

Czech Technical University in Prague, Faculty of Mechanical Engineering \& Faculty of Transportation Sciences, Department of Automobiles, Internal Combustion Engines and Railway Vehicles \& Department of Security Technologies and Engineering, Technická 4 \& Konviktská 20, Prague, Czech Republic

\section{SHRNUTÍ}

Současné metody vyšetřování dopravních nehod a struktura databází, uchovávající data o nehodách, umožňují hodnocení nehody z pohledu nehody samotné. Předkládaný článek nabízí nový prístup, popisující nehodu z pohledu vozidla, resp. systémů integrované bezpečnosti. Tento způsob umožní klasifikovat potenciální kolizi a na základě této klasifikace vyvolat nejvhodnějši zásah automatizovaných bezpečnostních systémů. Bylo definováno sedm kategorií, jejichž vlastnostmi lze definovat míru nutného zásahu takových systémů. Jedna z uvedených kategorií představuje také nový přistup $\mathrm{k}$ definování pravděpodobnosti střetu s jiným objektem. Na rozdíl od běžně užívané jednorozměrné veličiny TTC (time-to-collision), která je vysoce nestabilní, je definována nová veličina, tzv. reakční prostor, která je dvourozměrného charakteru a čas do ní vstupuje v podobě parametru, definujícího např. reakční dobu systému. Potřeba reakce je pak dána velikostí a charakterem průniku dvou nebo více reakčních prostorů. Reakční prostor tak umožňuje specifikovat okrajové podmínky nejen pro situaci brzdění, ale také vyhýbání. Závěrem článku je pak přehledná klasifikační stupnice, která dovoluje určit charakter bližíci se kolize, a tedy i potřebnou míru zásahu autonomních systémů nebo míru celkových následků takové nehody. Aplikace uvedené klasifikace je využitelná nejen pro základní porovnání nehod, ale i pro prímou analýzu vozidlovými systémy.

KLIĆCOV́ SLOVA: KLASIFIKACE, DOPRAVNÍ NEHODA, DOPRAVNII SYSTÉM, SILNIČNÍ VOZIDLO, REAKČNÍ PROSTOR.

\section{ABSTRACT}

Modern road accident investigation and database structures are focused on accident analysis and classification from the point of view of the accident itself. The presented article offers a new approach, which will describe the accident from the point of view of integrated safety vehicle systems. Seven main categories have been defined to specify the level of importance of automated system intervention. One of the proposed categories is a new approach to defining the collision probability of an ego-vehicle with another object. This approach focuses on determining a 2-D reaction space, which describes all possible positions of the vehicle or other moving object in the specified amount of time in the future. This is to be used for defining the probability of the vehicles interacting - when the intersection of two reaction spaces exists, an action has to be taken on the side of ego-vehicle. The currently used 1-D quantity of TTC (time-to-collision) can be superseded by the new reaction space variable. Such new quantity, whose basic idea is described in the article, enables the option of counting not only with necessary braking time, but mitigation by changing direction is then easily feasible. Finally, transparent classification measures of a probable accident are proposed. Their application is highly effective not only during basic accident comparison, but also for an on-board safety system.

KEYWORDS: ACCIDENT CLASSIFICATION, TRANSPORTATION SYSTEM, ROAD VEHICLE, REACTION SPACE.

\section{INTRODUCTION}

The main quality of the road transportation system could be described as a modification of efficiency, consisting of the number of people, goods and vehicles entering the system as divider for the number of unharmed people and undamaged goods and vehicles exiting the system. Such quality is observed by the number and severity of road accidents. Currently, road accidents are analyzed primarily from their own point of view, which means that we know how many vehicles were involved in an accident, how many people were injured, where and when the accident happened etc. Such information can be 
valuable for the overall design of a road system or for road user education. If we consider a car able to autonomously resolve a critical situation, then the car should know about the situation severity. Current vehicleintegrated safety systems do not use predictive methods for accident severity other than relative speed of possibly colliding vehicles. However, this is the only quantity, which the systems currently available on the market are capable of determining.

Current accident databases provide a vast amount of data. However, the accident classification seems to be very complex. If we consider the further development of vehicle integrated systems, then it is likely they will be given the ability of knowing how a severe accident can be mitigated or avoided. This would be highly valuable for autonomous vehicles, which should take a different decision according to vehicle occupation - driving with passengers or empty. This article presents a simplified accident classification method, which can be used by vehicles themselves. Such vehicle is able to classify the options for accident mitigation. Simplified classification can be performed on-board, thus a vehicle can estimate the severity of an unavoidable accident.

\section{CLASSIFICATION PARAMETERS}

Two main criteria have been set for defining classification parameters of an accident that will clearly describe the accident probability and severity: minimize the number of parameters, defining the accident, while maintaining the valuable information about accident severity. As an input, the road accident database maintained by the Czech Police road traffic police department was used. The author has performed an in-depth analysis of the database. The results, which are not included in this article, have produced interesting information. One thing in particular - a large amount of data is very unspecific and only vaguely describes the technical background of an accident process and consequences. The accident data is based mainly on legal consequences of an accident. However, every vehicle equipped with an integrated safety system has information about its current environment, which cannot be kept by the database. A combination of the road accident database analysis and a theoretical approach from the vehicle abilities perspective produced the following parameters that can clearly define the probability of an accident and the degree of damage:

1. rigidity of colliding objects;

2. contact cross-section of colliding objects in the normal direction of collision;

3. number of subsequent collisions;

4. vehicle relative speed before the expected accident;

5. type of collision;
6. vehicle movement during the accident;

7. vehicle occupation;

8. reaction space.

The above parameters can clearly describe the probable severity of an accident. To obtain information about the probability of collision, the parameter reaction space is added. Selection of the parameters, defining the severity of an accident, is based on the idea of the power of the accident process. We can define the power of a road accident as a ratio of the dissipated energy and the duration of motion $t_{\text {acc }}$ from the first contact to standstill of all the collision participants:

$$
P_{a c c}=\frac{E_{a c c}}{t_{a c c}}
$$

where

$$
E_{\text {acc }}=\sum_{i=1}^{n} f\left\{H_{i}, a_{i}, s_{i}, A_{i}\right\}
$$

where

- $E_{\text {acc }}$ defined by general function $\mathrm{f}$ is the total energy dissipated during the accident and represents the sum of the energy of all collisions that took place in the road accident;

- $H_{\mathrm{i}}$ is a momentum disproportion between the colliding objects;

- $a_{\mathrm{i}}$ is an average deceleration achieved by the collision;

- $s_{\mathrm{i}}$ is the distance where the two colliding objects were in contact;

- $A_{\mathrm{i}}$ is a ratio of direct contact cross-sections of colliding objects with respect to the size of their cross-sections in the direction of contact;

- $n$ is the number of collisions which occurred during the accident.

\subsection{PARAMETER 1:}

\section{COMPATIBILITY OF COLLIDING OBJECTS}

The compatibility of colliding objects, thus their rigidity in combination with momentum disproportion, is one of the quantities that define overall damage caused to the entities involved in a road accident. Unfortunately, it is the most difficult characteristic to analyze prior to collision. It can be done only partially in the case of determining typical shapes for detected objects such as a car, a pedestrian or a cyclist. In addition, reflectance in various spectrums of electromagnetic waves can be analyzed, and thus it should be possible to distinguish between i.e. a metal fence, a brick wall and a living being. However, the object description requires the cooperation of detection systems and considerable computing power, 
which will also allow a sufficiently fast search of a database of known objects. Acceleration of such analysis can be achieved primarily by sensor and data fusion methods, combining i.e. prediction of vehicle trajectory, stability of the state of the egovehicle and obstacle and, in particular, analysis of the driver state. Implementation of the human ability of abstraction and association in the computing system, which would allow the best analysis of the situation, is not feasible in the near future. On the other hand, human seems to be the most versatile sensor of all, and with considerable interdisciplinary cooperation, his perception of a situation in the exterior can already be detected at a relatively high level.

Currently, the compatibility analysis of the colliding objects is partially available only during the contact. In some minor cases, pedestrian detection is processed by fusing data from radar and camera systems. However, it is not known to the author whether current integrated safety systems modify their intervention according to such knowledge. It is expected that they don't, because only braking is currently performed as a safety manoeuvre. A specific case is the deployment of external pedestrian airbags, when the detection is based on contact forces and energies [1].

We can define three values for the specified classification parameter. They identify the relative rigidity of every two colliding objects in one of the subsequent or parallel collisions during a road accident:

1. the ego-vehicle is the object of higher rigidity and weight (or momentum) - i.e. collision with human, cyclist, light road barrier, small animal etc.;

2. both colliding objects are compatible - i.e. collision with another vehicle of the same type, large animal etc.;

3. the ego-vehicle is the object of lower rigidity and weight i.e. collision with larger and heavier vehicle, building etc.

\subsection{PARAMETER 2:}

\section{CONTACT CROSS-SECTION OF COLLIDING OBJECTS}

As already mentioned above, the shape of detected object can be used as a source for determining the type and rigidity of the obstacle. Currently, such detection is performed mainly by camera systems (2-D or 3-D) and by LiDARs. According to the shape of the object the prediction of contact areas can be performed. For example, a similar approach to pedestrian detection is already implemented in vehicles. In addition, relative motion of the colliding objects, obstacle and egovehicle, during the impact might be predicted. Therefore, the cross-section of the contact of the colliding objects is to be predicted. In addition, the position of centre of gravity of the obstacle with respect to the vertical size of the object has to be defined within the parameter.

1. the contact cross-section is over $75 \%$ of the ego-vehicle cross-section in the direction of contact;

a. the obstacle's CoG is lower than the upper limit of contact cross-section;

b. the obstacle's CoG is higher than or on the upper limit of contact cross-section;

2. the contact cross-section is max. $75 \%$ of the ego-vehicle cross-section in the direction of contact;

a. the obstacle's COG is lower than the upper limit of contact cross-section;

b. the obstacle's CoG is higher than or on the upper limit of contact cross-section;

3. the contact cross-section is max. $50 \%$ of the ego-vehicle cross-section in the direction of contact;

a. the obstacle's CoG is lower than the upper limit of contact cross-section;

b. the obstacle's CoG is higher than or on the upper limit of contact cross-section;

4. the contact cross-section is max. $25 \%$ of the ego-vehicle cross-section in the direction of contact;

a. the obstacle's CoG is lower than the upper limit of contact cross-section;

b. the obstacle's CoG is higher than or on the upper limit of contact cross-section.

\subsection{PARAMETER 3:}

\section{NUMBER OF SUBSEQUENT COLLISIONS}

The number of collisions in the accident, or number of participants in the accident, is important because of secondary impacts. If the safety systems were already involved in reducing first collision consequences, they cannot similarly act during another impact in similar contact areas. This happens, for example, when partially hitting guardrails and then an oncoming vehicle. From the ego-vehicle point of view, two values can be described that specify the main characteristics of such accident:

1. single collision - typical road accident of two objects or of ego-vehicle and several obstacles at one time;

2. multiple collisions discretized in time - specific type of cumulative accidents in time.

It is clear that the main difference between the above values for the ego-vehicle is in the activity of safety systems. For the first value, the number of objects which the ego-vehicle hits is irrelevant, as the contact with all of them is realized in a single moment. Such type of accident can be represented by the impact with another multi-vehicle collision. 
The second value is the most critical, as the safety systems are able to sufficiently protect the passengers primarily for the first collision. Currently, such disadvantage is being reduced by application of a multi-collision brake system which applies full braking power-thati.e. for Škoda orVolkswagen vehicles means deceleration of $6 \mathrm{~m} \cdot \mathrm{s}^{-2}$. This braking is applied automatically after the first collision occurs and slows the vehicle down to approx. $10 \mathrm{~km} \cdot \mathrm{h}^{-1}$ [1]. The question is, if there is a human capability to override the system when such vehicle behaviour is not appropriate according to the situation. Technically, the system can be overridden, but it cannot be expected that the driver suffering shock after the collision would be capable of performing the override. Multi-vehicle collisions are very rare, as are multiple collisions after or before hitting a non-vehicular obstacle. If we look at the analysis of the Czech road accident database [2] covering the years 2007-2011, performed by the author, we find the following data:

- multi-vehicular collisions (3 or more vehicles) account for about $5.4 \%$ of all road accidents investigated by the Czech police, which is on average 6400 accidents per year;

- about $6.3 \%$ of road accidents resulting in injury or death happen during multi-vehicular collisions, which is around 1500 accidents per year;

- multiple collisions (2 or more vehicles and a fixed obstacle) account for around $1.1 \%$ of all accidents (around 1300 per year);

- multiple collisions during a single accident increases the number of killed or injured people by only $0.9 \%$, or approx. 200 injured or killed people per year.

The above data does not conform with the data presented by marketing and press articles, which often indicate that such collisions represent around $25 \%$ of all accidents [1], [3]. Slight differences in the accident analysis results performed in different countries should be expected. However, such difference in the data obtained from raw data of the road accidents database and values presented by the media should be further researched. In addition, the probability of situations in which a multi-collision brake system would tend to create a new critical situation or collision, should be studied.

\subsection{PARAMETER 4:}

\section{VEHICLE RELATIVE SPEED AT THE TIME OF IMPACT}

The relative speed of impact is one of the main quantities for calculating the accident energy. Currently, the speed is the only input, which is relevant for legal mandatory and for commercial crash-tests. It originates in the biomechanical criteria for surviving the contact. The combination of speed with vehicle dimensions limits the maximum deceleration which can be reached during the contact. Vehicle dimensions in the context of the environment should not further increase in the future, thus the impact speed is the most relevant in terms of damage. In addition, for the integrated safety systems it is necessary to know whether the vehicle's relative speed is above the limit speed for an accident avoidance or mitigation manoeuvre.

The following values for the ego-vehicle speed ranges have been defined:

1. low speed - relative impact speed or relative intervehicular speed before impact relates to a maximum of half of the energy of impact during the relevant Euro NCAP crash test;

2. medium - relative impact speed or relative inter-vehicular speed before impact corresponds to $100 \%$ of the energy dissipated during relevant EuroNCAP crash-test;

3. high - relative impact speed or relative inter-vehicular speed before impact corresponds to a higher collision energy than $100 \%$ of relevant EuroNCAP crash test, but it can be decreased below this limiting value in the reaction space;

4. very high - within the reaction space, it is not possible to decrease such speed below the limiting speed, corresponding to the relevant EuroNCAP test.

\subsection{PARAMETER 5:}

\section{TYPE OF COLLISION}

The most common type of collision of two vehicles in the Czech Republic, regardless of the consequences of the accident, is the rear-end collision. If we focus only on inter-vehicular accidents with severe injuries and deaths, it is the frontal impact. The most common types of accidents with serious injuries or deaths are collisions with pedestrians $(25.2 \%)$ and collisions with a fixed obstacle (19.7\%). Frontal impact is recorded in $16.3 \%$ of severe accidents. However, in the case of collision

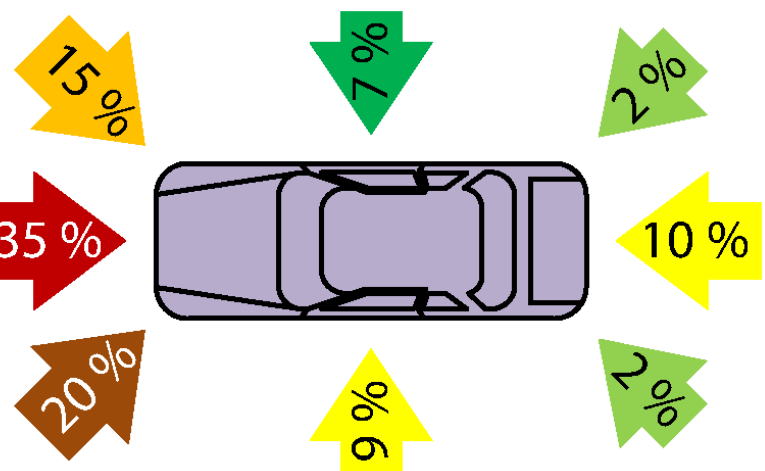

FIGURE 1: Impact orientation according to STATS19 [5] OBRÁZEK 1: Orientace nárazů dle STATS19 [5] 
with a pedestrian or a fixed obstacle, the impact orientation is not recorded in the database.

In contrast, the German GIDAS database identifies a side impact, for example at a crossroads (34.5\%), as the accident type with the most severe consequences. During the years 1996-1998, a quantitative research was performed in the south of the UK [4]. It was focused on a detailed analysis of accident database STATS19, which resulted in the knowledge of distribution of the most frequently affected parts of the vehicle, shown in Figure 1. Newer research of a similar motivation, which could already include the influence of active safety systems in vehicles, especially ABS and ESC, is not known to the author.

It can be expected that the frequency of specific types of impact will also vary with the location of accidents, road environs or people ethnicity etc. The optimal impact direction in terms of the severity of potential injury should obviously be in the direction of largest deformation zone of the vehicle, and thus the longest duration of the impact. Moreover, further movement, slow deceleration or partial rotation of vehicle upon impact can be accepted as positive manner when dissipating the vehicle's energy. However, the subsequent movement of the vehicle may have negative consequences for the surroundings and also increase the likelihood of secondary collisions.

A special accident case is a rollover, which, for example, had not been analyzed in the research of STATS19. In such type of accident the energy is dissipated in the vehicle rollover motion over a much longer period of time, in the best case causing smaller deformation in multiple parts of vehicle. Passive safety systems are only effective in terms of restraining occupants in the vehicle (seat belts, window airbags etc.). During such accident, the vehicle's safety cage has the main influence on passenger safety. The roof itself usually contains minimum elements that would be able to prevent the penetration of an external object into the cabin. The still growing popularity of SUVs and MPVs with a higher centre of gravity does not positively influence the number of rollover accidents. On the side of passive safety it is not possible to achieve adequate protection for the vehicle's crew during a non-ideal rollover accident. Therefore, it is necessary to primarily optimize the design of vehicle dynamics to minimize the probability of such accidents. Secondly, active and integrated safety systems can be fitted in the vehicle to prevent the chance of rollover. Currently, the ESC system is in charge of rollover protection systems and is mandatory in the homologation process for the European Union since November $1^{\text {st }} 2011$ [4]. For all new cars sold, the regulation shall apply from November $1^{\text {st }} 2014$.
For the specified parameter the following values from the perspective of the ego-vehicle have been selected:

1. side-to-side impact;

2. rear-end impact;

3. rear-end and side impact combination;

4. frontal impact;

5. frontal and side impact combination;

6. rollover accident;

7. side impact (T-bone collision).

\subsection{PARAMETER 6:}

\section{VEHICLE MOVEMENT DURING AN ACCIDENT}

The safety of vehicle occupants will be best ensured by avoiding any impact, or at least the secondary ones. Road design itself anticipates the existence of several defined types of objects which may come into contact with the vehicle. Integrated and active safety systems are designed to expect the existence of clearly definable objects, based on the road transportation system design and purpose. From the perspective of active and integrated safety systems, the movement of the vehicle outside of the road is highly undesirable, since the vehicle enters an environment which is most likely to contain unidentified components, thus limiting correct operation of such systems. Still, the existence of situations where off-road movement of the vehicle is desirable and complies with the minimum safety requirements has to be approved.

The road, road equipment design and its surroundings have a fundamental influence on the operational safety of road traffic itself, but also on the safety of road users in the road environs. During the road design process, some probability of road accidents has to be expected. Hence the road design should be performed in terms of minimizing possible damage and injuries.

Even in cases where there is no collision with an obstacle on the road, i.e. during skidding, it is not clear whether leaving the road has a positive or negative influence on safety without the knowledge of the accident surroundings. Such broader analysis of a vehicle's environment would be highly beneficial for the autonomous intervention of safety systems.

The defined parameter is indicated by following values:

1. ego-vehicle stays on the road without contact with another object;

2. ego-vehicle stays on the road due to contact with another object (or after contact);

3. ego-vehicle leaves the road before the primary impact;

4. ego-vehicle leaves the road due to the impact (one or more). 


\subsection{PARAMETER 7:}

\section{VEHICLE OCCUPATION}

The suggested parameter of vehicle occupation is not focused on investigating the probable injuries that could occur to the passengers. From the technical perspective of an integrated safety system, the conditions leading to the accident and the probability of injuring anybody is essential. Thus, vehicle occupants are perceived as a load that influences vehicle behaviour during manoeuvring and their distribution in the vehicle corresponds to load distribution. In addition to completely autonomous systems, such system should know if the vehicle is running with or without passengers, which greatly influences the perception of safety and security - a vehicle driving without passengers can be completely destroyed, if this helps save the lives and health of other road users. Thus, the following values have been selected for the parameter:

1. no passengers - autonomous vehicle is driving without any passenger (i.e. taxi-on-demand service);

2. driver only;

3. vehicle's load is balanced;

4. vehicle tends to pitch due to unbalanced load;

5. vehicle tends to roll due to unbalanced load.

\subsection{PARAMETER 8:}

\section{REACTION SPACE}

Having sufficient reaction space is necessary to identify and analyze the critical situation, prepare an appropriate manoeuvre and perform it. Such space is primarily designated by the environment in which the vehicle is currently moving. Let's define such reaction space $\varepsilon$ as a quasi-2D area, whose theoretical boundary is limited by the position of the vehicle in the next $\mathrm{n}$ seconds. This space can be divided into two subspaces:

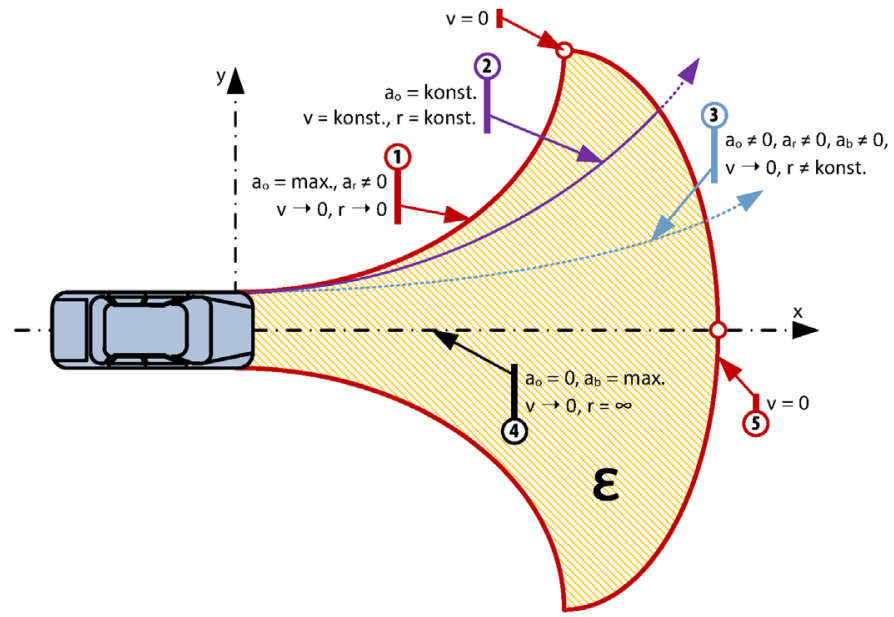

FIGURE 2: Schema of reaction space OBRÁZEK 2: Schéma reakčního prostoru
1. the first space in which the vehicle may be located during the manoeuvre to prevent collisions, i.e. either performs braking, an evasion manoeuvre or both - this space is bounded in Figure 2 by the red curves 1 and 5 and is denoted $\varepsilon$;

1. the second space in which the vehicle may be located while maintaining a constant driving speed - this space is shown in Figure 2 bounded by the purple line 2, and let it be called $\varepsilon_{0}$. Unlike for the space $\varepsilon_{\text {, the }} \varepsilon_{0}$ is not restricted by the vehicle stopping distance and continues beyond the red line No. 5. During such manoeuvre the vehicle speed is not decreased by the vehicle resistance.

The diagram in Figure 2 indicates the character of the reaction space of the vehicle. Its boundaries are specified by several curves, which are determined by the dynamic capabilities of the vehicle. For the depicted reaction space, a simplified mass point model of the car is used. The extension to the model with dynamic properties of a particular car is not essential for the current work. The diagram indicates the main limit curve labeled $1-5$, with the following specifications:

1. Curve no. 1, characterized by a maximum attainable combination of centrifugal acceleration and deceleration due to vehicle resistances $a_{\mathrm{r}}$. It is therefore a curve whose radius of curvature $r$ decreases with the length of the curve $s$ and whose end point is defined by zero vehicle speed $v$. This curve is a clothoid (Euler spiral) [7] with the following derived parametrical definition:

$$
\begin{aligned}
& x=\int_{0}^{T} \cos \frac{\kappa}{a_{r}^{3} t^{2}} d t \\
& y=\frac{b}{2}+\int_{0}^{T} \sin \frac{\kappa}{a_{r}^{3} t^{2}} d t
\end{aligned}
$$

where

- $x$ is the direction of travel of the vehicle,

- $a_{\mathrm{r}}$ is the instantaneous deceleration of the vehicle,

- the variables $t$ and $T$, express either the time to stop or the time for which it is necessary to know the position of the vehicle in the future,

- $\quad$ and $b$ is the width of the vehicle.

The vehicle's immediate deceleration ar is given only by the vehicle resistances - air resistance, rolling resistance, cornering resistance or the resistance of slope. Constant $\kappa$ is defined by the following equation:

$$
\kappa=\frac{1}{4} v_{0} \mu_{\max } g
$$


where

- $v_{0}$ is the initial speed of the vehicle,

- $\mu$ max is maximum achievable coefficient of adhesion between tire and road,

- $g$ is the gravitational acceleration.

Further, the values for the length of the clothoid and for its radius are the input for the original equation of clothoid. Thus, by processing simple mathematical modifications we obtain the final equation Eq. 3 above. For the length $s$ and radius $r$ of clothoid, the following relationships are used:

$$
\begin{aligned}
s & =\frac{v_{0}^{2}}{2 a_{r}} \\
r & =\frac{v^{2}}{a_{c}}=\frac{v^{2}}{\mu_{\max } g} \\
d v & =a_{r} d t
\end{aligned}
$$

where

- $s$ is the length of clothoid,

- $r$ is the current radius of clothoid,

- $a_{c}$ is the maximum centrifugal acceleration,

- $\quad v$ is the current speed of the vehicle.

2. Curve no. 2 is defined by the maximum centrifugal acceleration $a$ too, but with the car driving at constant speed. Therefore it encloses an area in which the vehicle is present when not responding to a critical situation. Such boundary curve is specified by constant radius, and therefore it is a circle:

$$
\begin{aligned}
& x=\frac{v_{0}^{2}}{\mu_{\max } g} \cos \frac{\mu_{\max } g t}{v_{0}} \\
& y=\frac{b}{2}+\frac{v_{0}^{2}}{\mu_{\max } g} \sin \frac{\mu_{\max } g t}{v_{0}}
\end{aligned}
$$

3. Curve no. 3 is a trajectory of the vehicle when centrifugal acceleration reaches a maximum for a certain degree of braking force. In such case it is necessary to also count with braking deceleration. It is again a clothoid.

4. Curve no. 4, or rather a straight line, is the trajectory on which the maximum deceleration is achieved, while maintaining zero centrifugal acceleration. It is defined by a simple parametric equation:

$$
\begin{aligned}
& x=\int_{0}^{T}\left(\mu_{\max } g+a_{r}\right) t d t \\
& y=0
\end{aligned}
$$

5. The reaction space is enclosed by the endpoints of all clothoids, covering all combinations of deceleration and cornering, in which the vehicle has zero velocity. The maximum value of the combined acceleration, or deceleration, is based on the so-called G-G diagram. It characterizes the contact between the tire and the road surface (see Figure 3), expressed in terms of achieved centrifugal acceleration $a_{c^{\prime}}$ braking and resistive deceleration $a_{\mathrm{b}}+a_{\mathrm{r}}$ and forward acceleration $a_{\mathrm{a}}$ which is primarily limited to a power of the vehicle. Such curve is clothoid again, this time symmetrical about the $x$-axis and passing through its zero point.

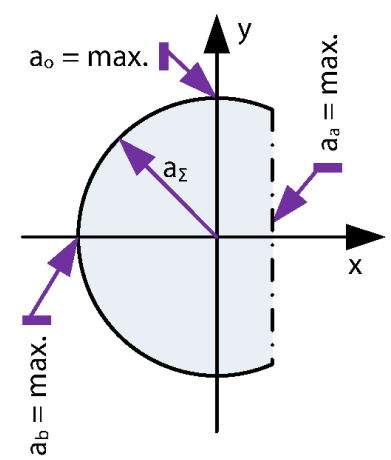

FIGURE 3: G-G diagram OBRÁZEK 3: G-G diagram

The resulting reaction space is bounded by the above curves. The calculation includes several known quantities - initial velocity, vehicle deceleration, physical constants and dimensions of the vehicle - then one quantity depending on the instantaneous vehicle speed - the deceleration based on vehicle resistances and finally a parameter of required scope of knowledge about the movement of the vehicle in the future, which is time.

Relating the reaction space to the time base is particularly advantageous in terms of ease of measurement. Calculating the probability of intersection of multiple reaction spaces of other vehicles and road users in the ego-vehicle's vicinity also allows more simple prediction of hazardous situations than the application of TTC.

Furthermore, the reaction space can be simply extended to the monitored area by changing the time parameter and increasing the offset from the axis of the ego-vehicle. Sufficient size of the monitored area is one of the major variables influencing the ability to clearly predict future behaviour of the ego-vehicle's environment. The size of monitored area is also closely connected with the reaction time of the driver and vehicle systems.

The reaction space is closely related to speed before reaction. As the reaction space gets smaller, the limit speed for performing an accident avoidance manoeuvre also decreases, 


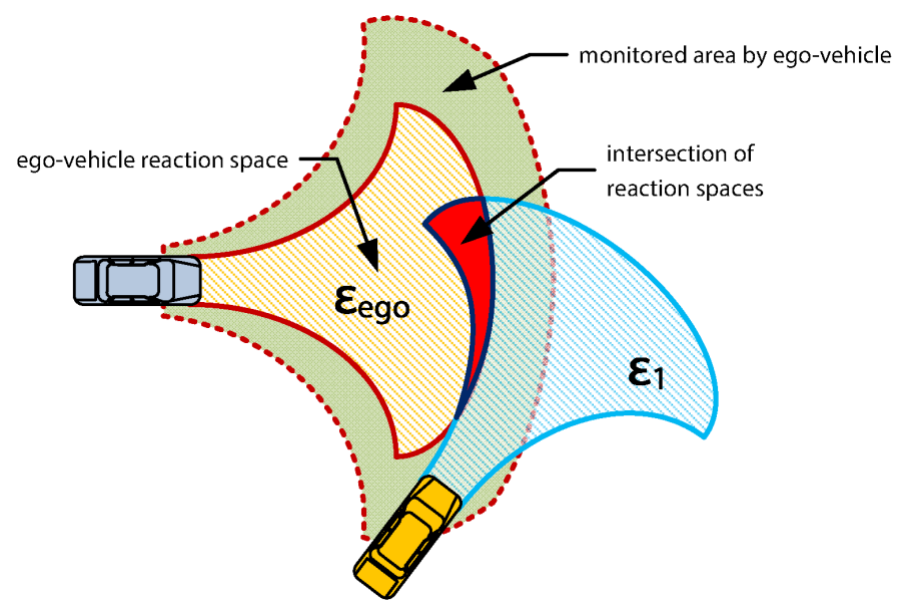

FIGURE 4: Example of intersection of two reaction spaces OBRÁZEK 4: Př́klad průniku dvou reakčních prostorů

and vice versa. Nevertheless, it is necessary to know whether and how it is possible to perform a reaction in the reaction space and if the reaction is absolutely necessary. It is always advisable to consider whether mitigation of anticipated risks could cause more damage than the accident or risk itself. Such analysis should be essentially performed in terms of minimizing injuries, regardless of the material damage.

Generally, the reaction space itself is always influenced by the road environment and current traffic situation. In some cases, it may be that braking is the only feasible reaction. Therefore, the reaction space can be used not only from the vehicle's perspective, but it can also be beneficial for the road design when determining i.e. the maximum allowable speed. When the application of dynamic traffic control takes control, the traffic density should be the main input parameter for the reaction space.

For the classification purposes, the parameter is defined by following values:

1. practically unlimited reaction space - the reaction space for the predefined time is not limited by obstacles;

2. the reaction space is limited in the $y$-direction (across the direction of travel);

3. the reaction space is limited in the $x$-direction (in the direction of travel);

4. the reaction space is obstructed in the y-direction only braking is feasible;

5. the reaction space is obstructed in the x-direction - only an avoidance manoeuvre is feasible;

6. the reaction space is limited in both directions - collision mitigation is possible, but the impact is unavoidable;

7. the reaction space is obstructed in both directions no accident mitigation is feasible.

\section{CLASSIFICATION METHOD}

With the above parameters it is possible to clearly specify the type of accident for application in integrated safety systems design or for the real-time characterization of the detected potential accident. To have such classification easy to read and compare, all the values of each parameter are combined in a single "word" in the following format: ABa.CDE.FG-H, where each letter stands for the value of every parameter in the following order with defined minimum and maximum parameter values:

A rigidity of colliding objects - parameter values from 1 to 3 ;

B contact cross-section of colliding objects in the normal direction of collision - value 1 to 4;

a. sub-parameter defining the position of center of gravity of the obstacle - value a or b;

C number of subsequent collisions - values 1 or 2;

D vehicle speed before the expected accident values 1 to 4 ;

E type of collision - values 1 to 7;

F vehicle movement during the accident - values 1 to 4 ;

$G$ vehicle occupation - values 1 to 5 ;

$\mathrm{H}$ reaction space - values 1 to 7 .

The reaction space can be treated as a value that defines the risk potential of the specific accident. Similarly, values of each parameter are sorted from the least dangerous to most dangerous. Hence, the accident described by 11a.111.11-1 is the least severe accident with almost zero risk of occurring due to the largest reaction space with no intersection with other objects. On the other hand, an accident designated 34b.247.45-7 is the most severe accident type, with a probability of almost $100 \%$.

When using the potential accident classification with an invehicle safety system, the main parameter is the reaction space. According to its size and constellation of vehicles and obstacles in the reaction space the possible accident scenarios can be predicted and sorted according to the proposed classification. This allows definition of the optimum trajectory based on minimum expected damage, or based on minimum intersections of reaction spaces. As the reaction space is not based on TTC quantity, it is possible to continuously alter the scenarios according to the driver's interventions.

\section{CONCLUSION}

Creation of a basic set of classification parameters and their values define a simple and comparable description of a road accident and its severity. Validation of the application of 
the proposed simple classification method, in particular in a vehicle, is a task for further research. The description can either be used for classification of road accidents in the accident databases with application in vehicle integrated safety system design, or for direct use in a vehicle detection system. Then the estimation of accident probability is enhanced by prediction of accident severity. The probability of collision or a risk situation is defined by intersections of reaction spaces of the egovehicle and other road users and vehicles. These intersections also specify the possible reactions that could be performed by the ego-vehicle. Application of reaction space, where time is an input quantity instead of a result, as in a 1-D time-to-collision method, enhances further predictive capabilities of integrated safety systems to include prediction of movement of other road users. The article presents the concept of reaction space as a part of the proposed accident classification system and thus it is gives only a general idea of its practical application, which will be studied further.

\section{ACKNOWLED GEMENTS}

This research has been realized using the support of Technological Agency, Czech Republic, programme Centres of Competence, project \# TE01020020 Josef Božek Competence Centre for Automotive Industry. This support is gratefully acknowledged.

\section{LIST OF NOTATIONS}

\section{AND ABBREVIATIONS}

1-D one dimensional

2-D two dimensional

3-D three dimensional

GIDAS German In-Depth Accident Study

LiDAR Light Detection And Ranging

MPV Multi-Purpose Vehicle

STATS19 designation of UK road accident database

SUV Sport Utility Vehicle

TTC Time-To-Collision

\section{REFERENCES}

[1] P. K. Zoratti, J. A. Bochenek and D. Ming Chi, „Vehicle impact sensing system". USA Patent US6929282 B1, 16 August 2005.

[2] „VW Multi Collision Brake," EuroNCAP, [Online]. Available: http://www.euroncap.com/rewards/vw_multi_ collision_brake.aspx. [Accessed 3 November 2014].

[3] Policie ČR, Road accident database 2007-2011, unpublished raw data.

[4] J. Sajdl, „Multikolizní brzda," [Online]. Available: http://cs.autolexicon.net/articles/multikolizni-brzda. [Accessed 3 November 2014].

[5] R. Young, "Cognitive Distraction While Driving: A Critical Review of Definitions and Prevalence in Crashes," SAE Int. Journal of Passenger Cars - Electronic and Electrical Systems, Vol. 5, No. 1, pp. 326-342, 2012.

[6] Regulation (EC) no. 661/2009 of the European Parliament and of the Council concerning type-approval requirements for the general safety of motor vehicles, their trailers and systems, components and separate technical units intended therefor, Bruxelles: European Union, 2009.

[7] K. Rektorys, Přehled užité matematiky, 2. ed., Praha: SNTL - Nakladatelství technické literatury, 1968, p. 1140.

[8] P. Soukup, „Nesprávná užívání statistické významnosti a jejich možná řešení.," Data a výzkym - SDA Info, Vol. 4, No. 2, pp. 77-104, 2010.

[9] D. L. Hibberd, "Managing in-vehicle distractions: evidence from the psychological refractory period paradigm," in Proceedings of the $2^{\text {nd }}$ International Conference on Automotive User Interfaces and Interactive Vehicular Applications, New York, 2010.

[10]C. Rousseau and M. Huard, "Automotive Radar on the Move. Towards international frequency harmonisation," in $79 \mathrm{GHz}$ project workshop, Tokyo, 2013.

[11] „Design Principles for Advanced Driver Assistance Systems: Keeping Drivers In-the-Loop.," UNECE, International Harmonized Research Activities (IHRA), 2010.

[12] M. Kuehn, T. Hummel and J. Bende, „Benefit estimation of advanced driver assistance," in Proceedings of the $21^{\text {st }}$ International Technical Conference on the Enhanced Safety of Vehicles Conference (ESV), Stuttgart, 2009.

[13] H. Andersson, „Longitudinal functionality introduction,” in eValue final demonstration event, Santa Oliva, 2010.

[14]K. Reif and et al., Automotive handbook, 8 ed., Plochingen: Robert Bosch GmbH, 2011, p. 1265. 